\title{
Journal of Education
}

\section{ISSN Online: 2616-8383}

\section{TH Stratford

Relationship between Church Appointed School Administrative Leadership and the Management of the Students' Unrest in Siaya County

Makhungu Antonina Isalano (Sr), Dr. Vincent Omwenga, Dr. Magdalene Dimba \& Dr. Bernard Shibwabo 
Stratford Peer Reviewed Journals and Book Publishing

Journal of Education

Volume 4||Issue 5 ||Page 94-107||October||2021|

Email: info@stratfordjournals.org ISSN: 2616-8383

\title{
Relationship between Church Appointed School Administrative Leadership and the Management of the Students' Unrest in Siaya County
}

${ }^{* 1}$ Makhungu Antonina Isalano (Sr), ${ }^{2} \mathrm{Dr}$. Vincent Omwenga, ${ }^{3} \mathrm{Dr}$. Magdalene Dimba \& ${ }^{4}$ Dr. Bernard Shibwabo

\author{
${ }^{1}$ Masters' Student, Strathmore University- Kenya \\ ${ }^{2}$ Senior Lecturer, School of Humanities and Social Sciences, Strathmore University- \\ Kenya \\ ${ }^{3}$ Dean, School of Humanities and Social Sciences, Strathmore University-Kenya \\ ${ }^{4}$ Director of Graduate Studies, Strathmore University-Kenya
}

E-mail of Corresponding Author: aisalano@gmail.com

How to cite this article: Isalano, M. A., Omwenga, V., Dimba, M. \& Shibwabo, B. (2021). Relationship between Church Appointed School Administrative Leadership and the Management of the Students' Unrest in Siaya County. Journal of Education, 4(5), 94107. https://doi.org/10.53819/81018102t4014

\begin{abstract}
This study analyzed the relationship between church appointed school administrative leadership and the management of the students' unrest in Siaya County. The study was underpinned on the structural functioning theory. The study targeted catholic sponsored secondary schools in the county from which the sample size was taken. The study adopted a pragmatic approach method therefore employing concurrent triangulation mixed method design. Questionnaires, interviews and document analysis were used as data collection methods. The quantitative data was analyzed descriptively through frequencies and percentages using SPSS Version 26. Qualitative data was transcribed and analyzed through content analysis approach. The outcome of the study was evidence of disparities between numbers of student unrest among the church appointed school administrator institutions in comparison to the government appointed school administrator institutions. The church appointed administrators had less incidences of student unrest in comparison to those schools with government appointed administrators and this difference was statistically significant. The findings indicated a positive and significant correlation between church appointed administrative leadership and sponsorship of development projects with the management of student unrest. The study concludes that student involvement and inclusion in planning of development projects of church sponsors and students would contribute to the reduction of student unrest cases. The study thus recommended that the sponsor should actively
\end{abstract}




\section{Stratford Peer Reviewed Journals and Book Publishing \\ Journal of Education \\ Volume 4|| Issue 5 ||Page 94-107||October||2021| \\ Email: info@stratfordjournals.org ISSN: 2616-8383}

participate in school operations for stability; facilitation of spiritual guidance and development projects. There is need for more channels of communication between students, the church, and school management on issues and matters that may result in student unrest.

Keywords: Church appointed, School administrative, Leadership, Management Students' unrest, Siaya County.

\subsection{Background to the Study}

The management of education facilities in Kenya can be either public, private, or church sponsored (Wamunyu, 2012). The Ministry of Education (MoE) and the Board of Governors Order recognizes that sponsors recommend chairperson of the school board who should be recommended by the MoE. The Education Act (2013) further provides that the sponsor should commend and prepare endorsement by the department in charge of education resources for learning religious education in sponsored schools as provided for in regulation five (Mabeya, Ndiku \& Njino 2010).

Kenya's Basic Education Act (2013), gives provision for church sponsor to participate in the management of the school by appointing the school manager and maintaining religious traditions and church doctrines in schools they sponsor by offering pastoral services, ensuring security by reinforcing employment of sufficient personnel and school fencing. The Act similarly provides the role of the church sponsor to be involved in student discipline management, formation of character and inculcation of moral values towards the achievement of the national goals of education.

The Kenyan government after achieving independence recognized the function played by the church in education management and development. The government acknowledged that it was necessary for Christian churches to support financial resources in the management of the education sector due to poor financial resources for the post-colonial government (Gikungu, Karanja \& Thinguri, 2014). These schools started by the church, were under the sponsorship of these religious institutions, but were registered as public schools (Gikungu et al., 2014). One of the challenges facing secondary schools in the 21 st century has been student conflicts (Chemutai, Onkware \& Iteyo, 2020). Student unrest has not been a new phenomenon but has been a recurring issue in Kenya secondary schools in varying degrees and during specific durations. The history of education in Kenya shows that student unrest has been a frequent occurrence since 1970s (Republic of Kenya, 2017).

In 2016, there were a total of 483 incidents of student unrest which included 239 cases of fire and 244 other forms of unrest (Kagwanja, 2016). In second term alone, the incidents were 429 which constituted $88.81 \%$ of the incidents which occurred in 2016 . The unrest was manifested in terms of burning of administration blocks, canteens, dormitories, and classrooms. Out of the 282 buildings burnt, 228 (80.85\%) were dormitories. There were also cases of arson, general destruction of school and students' property, boycott of classes and examinations, walkouts, sit-ins, written and verbal threats to administration (Special Investigating Team, 2016).

Student unrest has occurred in church sponsored secondary schools which have often been seen as institutions that have a greater moral formation due to sponsorship by the church. According to Gikungu and Karanja (2014), church involvement in management of schools was a major strategy of curbing students' unrest. However, this is not the case, for example, in 2008, a Queen of Apostles, a junior church sponsored seminary, two big dormitories were 


\section{Stratford Peer Reviewed Journals and Book Publishing \\ Journal of Education \\ Volume 4||Issue 5 ||Page 94-107||October||2021| \\ Email: info@stratfordjournals.org ISSN: 2616-8383}

burned down and property worth millions of shillings were also destroyed (Muli, 2012). In another investigation, Romata (2008) noted that determinants of indiscipline stemmed from adolescents' new roles in society, rigorous studies, violence and crime shown in media, and weakened family and home structures among Catholic sponsored secondary schools in Nyeri County. In Kitui, over 40 secondary schools were involved in unrest and 15 out of these were catholic sponsored schools (Muthamba, 2017).

A Nation Media Group (July, 31, 2018) indicated that a total of 107 cases of students' unrest had been reported in secondary schools in 2018 with arson cases reported as sixty-three. The report by special investigation team on students' unrest (2016) observed that majority of the sponsors from the 97 public secondary schools visited nationwide were not playing roles as expected. These included the catholic and protestant sponsored schools. In most of the schools visited, spiritual care was unstructured or non-existent despite the fact that majority was sponsored by church organizations. The sponsors had little or no involvement in spiritual programs for students and this contributed to the student unrest. These exposed students to negative ideologies and values that resulted into students' unrest characterized by destruction of property, injuries and loss of life.

Muindi (2010) indicates that the support for church sponsorship in schools was aimed to save the parents and the nation from stress and loss associated with student unrest in secondary schools by providing holistic and religious values formation that would contribute to positive behavior among learners. Mabeya, Ndiku \& Njino (2010) asserted that missionaries had a major part to play in the development and maintenance of all learning institutions they sponsored as they supported development projects in schools. This shows the importance of church sponsorship was an appreciated incentive into financing education.

Ouma (2015) noted that the sponsor assisted by recruiting and appointing school managers, extra board-recruited teachers, building libraries, laboratories, classroom, and giving bursaries to students in need thereby enhancing development out and in the school environment. Fuller and Johnson (2014) argue that the school success where sponsors are enhanced in everyday operations of the school is due to shared roles in academic programs, extra-curricular activities and religious activities.

There is some evidence that church sponsorship has not had the desired effects on the management of secondary schools. One such study is that of Kihanya (2015) that revealed that the significant barrier for head teachers were sponsors who were overly strict in terms of the faith practiced in the school and this resulted in more issues such as appointment of board members leading to student unrest. Additionally, findings established head teachers faced challenges with strict sponsors with problems arising from the appointment of school leadership and this could have an effect on student indiscipline and unrest. Itumbiri (2012) found that church sponsors representatives in the management reduces mismanagement of resources and student discipline. Mosomi and Zachariah (2017) found that sponsors interrupted their mandate such as insisting on supervision of projects in the schools.

The foregoing literature shows the importance of church sponsorship in Kenya's education. However, the evidence (Romata, 2008; Muthamba, 2017; Gikungu \& Karanja, 2014; Muli, 2012) also show that the involvement of church in financing and management, appointment of school managers or administrators, and moral and religious values of education would lead to greater moral standing among learners and this would have a positive effect on reducing and managing student unrest. This is an area that this study aims to explore. 


\section{Stratford Peer Reviewed Journals and Book Publishing \\ Journal of Education \\ Volume 4|| Issue 5 ||Page 94-107||October||2021| \\ Email: info@stratfordjournals.org ISSN: 2616-8383}

\subsection{Statement of the Problem}

The foregoing literature indicates that the sponsorship of education by the church in Kenya was based on financing education and along with this, sponsorship of education was anticipated to also contribute to instillation of spiritual values that would provide the holistic formation of learners in the education system. Church sponsorship was seen to also be able to deal with the rising issues in secondary education where there was prevalence of student unrest several decades after the post-colonial government took over the education sector.

Despite church sponsorship and involvement in the appointment of school administrators, spiritual guidance, and sponsorship of development projects in schools; the number of student unrest in church sponsored schools has still occurred in recent years Gikungu \& Karanja, 2014; Muli, 2012; Romata, 2008; Muthamba, 2017). This student unrest has been manifested in destruction of school property, loss of life, fatalities, injuries to teachers and students as well. These incidences of student unrest have an indication of criminal intent many of which have caused a public outcry hence the timely and urgent need for the current study. Several studies (Chepkawai, 2014; Kesui, Manduku \& Sang, 2017; Chemutai et al, 2020) have examined the factors that lead to student unrest in church-sponsored schools but there is less evidence of studies that have examined the influence of church sponsorship and involvement in the appointment of school administrators, spiritual guidance, and sponsorship of development projects on managing student unrest which is a gap that this study aims to fill.

\subsection{Objective of the Study}

To analyze relationship between church appointed school administrative leadership and the management of the students' unrest in Siaya County.

\subsection{Research Question}

Is there any relationship between church appointed school administrative leadership and the management of students' unrest in Siaya County?

\subsection{Theoretical Framework}

The structural functioning theory argues that an organization has several groups of various individuals working in harmony towards a common goal (Parsons, 1956). The theory views society as a complicated system of parts which work in harmony promoting stability and solidarity. The structural functioning theory aims to explain the functioning and stability by summarizing the four functional requirements for any system and these are goal attainment, latent pattern maintenance, integration, and adaptation. The adaptation component refers to the problem of acquiring needed resources to meet the needs of the institution through planning (The Basic Education Act, 2013 section 59 (c)), Goal Attainment: the problem of setting and implementing goals, directed by laws passed by the government (The Basic Education Act, 2013).

The integration component refers to the challenge of maintaining coordination or solidarity in the parts of the system via monitoring. The latent component of the theory argues the issue of transmission, preservation, and creation of the systems unique value and culture for the aim of making sure efficient and effective delivery of basic education (The Basic Education Act, 2013). The theory proposes that many firms are complex and large social units comprising of several sub-parts which aim to understand the association between the whole system and the parts in a firm and specifically on stability for their achievements. The theory thus 


\section{Stratford Peer Reviewed Journals and Book Publishing \\ Journal of Education \\ Volume 4||Issue 5 ||Page 94-107||October||2021| \\ Email: info@stratfordjournals.org ISSN: 2616-8383}

appropriately explains the interaction of the church sponsorship and public secondary schools in management of students' unrest in Siaya County.

The structural functionalism theory views the school as a system, that is, a social system that features the integration of various parts, a unique population, a complicated network of social relationships and its own particular culture (Hoy, Miskel \& Tarter, 2019). In these subsystems there is interaction with each other in the environment. In this research, the church sponsored secondary school sub-systems consist of Board of Governors (BOG), students, government, sponsors, Parent Teachers Association (PTA), teachers, support staff and administration. The sponsor being a sub-system, its interaction with the school by appointment of school administrative leadership, facilitating spiritual guidance, and sponsorship of development projects should enhance discipline and therefore effect the management of students' unrest.

Other studies have used the theory in their investigations; these include Mabeya et al. (2010) investigation that found sponsor expectations of the school administrators on students and teachers had an effect on school operations as a system. Odindo (2016) used social functioning theory in examining role of religious sponsors in management of student discipline in public schools in Kisumu West County noting that church sponsors as a sub system of the school should actively be involved in management of students' discipline.

The theory is of importance to this research as the sub-system interaction described by the theory applies to the sponsor, learners, school administration, and the government as the different sub-systems that have to work in harmony in terms of the appointment of the school administrators, enhance participation in sponsorship of school development projects and participate in the spiritual formation and guidance of students. These sub-systems working in harmony in view of the three independent variables are assumed to have an impact on the management of student unrest.

\subsection{Empirical Literature}

Karanja and Bowen (2012) indicate that student unrest is a global occurrence that spans political, economic, geographical and racial as well as gender boundaries. According to Amine (2015), student unrest is the participation of students in demonstrations, strikes, mass meetings, walkouts, processions, burning of school property, murder and violent confrontation with the administration and the immediate community. Student unrest is manifested in schools in the form of strikes, riots, demonstrations, protests, boycotts, sit-inns, harassment and other violent forms. This section of the review focused on past empirical studies that have examined the relationship between the study variables.

A study conducted by Kate (2016) in Nigeria among a sample of 25 staff and 175 learners aimed to assess the causes of student unrest using a case study research design. The findings established that student unrest was caused by dissatisfaction of handling of matters by principals, low morale, low academic performance and poor advice of parents. The direct effects are the reprimand of students with the complaints of chance transfer of staff and poor feeding. The study recommended that there was need for effective and organized use of student press to motivate learners to make constructive critiques in the college and the school administration should adopt strict measures to maintain regulations and rules in the schools. The findings suggest the importance of communication between the students, management and any other sponsor. However, the role of sponsor of schools was not examined and this is a focus of this study. 


\section{Stratford Peer Reviewed Journals and Book Publishing \\ Journal of Education \\ Volume 4|| Issue 5 ||Page 94-107||October||2021| \\ Email: info@stratfordjournals.org ISSN: 2616-8383}

An earlier study conducted on management of public high schools through churches in Kiambu County was done by Kihanya (2015) targeting PTAs, churches, teachers and principals. The results indicate that in most schools under area of study, school administrators and the sponsors were quarreling over the school management issues. It was revealed that the significant barrier for head teachers were sponsors who were overly strict in terms of the faith practiced in the school and this resulted in more issues such as appointment of board members. The study showed the problems that may arise from the appointment of school leadership and this could have an effect on student indiscipline and unrest but this was not investigated in this study and this is a gap the study will fill.

In an aim to describe the nature of secondary schools' student unrest in Kericho County, Chemutai et al. (2020) adopted the functionalism and participative leadership theory using an evaluation research design. The respondents from the study were from the BOG, education officers, teachers, head teachers and students. It was revealed that students in day schools would be violent towards each other at the end of the day as there was no authority. The study did not examine role of church-sponsorship and how they can manage student unrest.

In evaluating effectiveness of communication among school administration and students, Onditi (2019) used the progressive education theory and the participative leadership theory and targeted secondary school head teachers, deputy head teachers and student leaders. The data was collected using questionnaires and interview schedules adopting a mixed method approach. The results revealed there was a lack of clear channels of communication between the head teacher and other education stakeholders, especially the students suggesting that the lack of communication between the administrative leadership and the students would result in student unrest. In assessing democratic decision-making and unrest among learners in Elgeyo Marakwet, Chepkawai (2014) used stratified random sampling to select 10 schools and 72 participants. The data was collected using document analysis and questionnaires. The study found that through such communication, rumors, suspicions and bad plans would be done away with regarding school administration which has often resulted in student unrest. The study, however, did not explore how church sponsorship factors can contribute to management of student unrest.

Adopting a descriptive research design to examine the part of church sponsor on academic performance of learners in Uasin Gishu Coumty, Mabeya et al. (2010) adopted a descriptive survey design targeting public Christian church sponsored secondary schools in which the 97 head teachers and 7 education secretaries were the sample size. The study found that sponsor expectations on student and teachers had an effect on the operations of the school and also a relationship was found between academic performance and sponsor. The study recommended that there was need to examine particular governance and church sponsor of secondary schools to establish the function of sponsor in increasing the schools' stability. The study did not however examine the role of the sponsor in appointing school administrators and sponsoring development projects and their influence on student unrest, a gap that this study aims to fill. 
Stratford Peer Reviewed Journals and Book Publishing

Journal of Education

Volume 4||Issue 5 ||Page 94-107||October||2021|

Email: info@stratfordjournals.org ISSN: 2616-8383

\subsection{Conceptual Framework}

Independent Variable

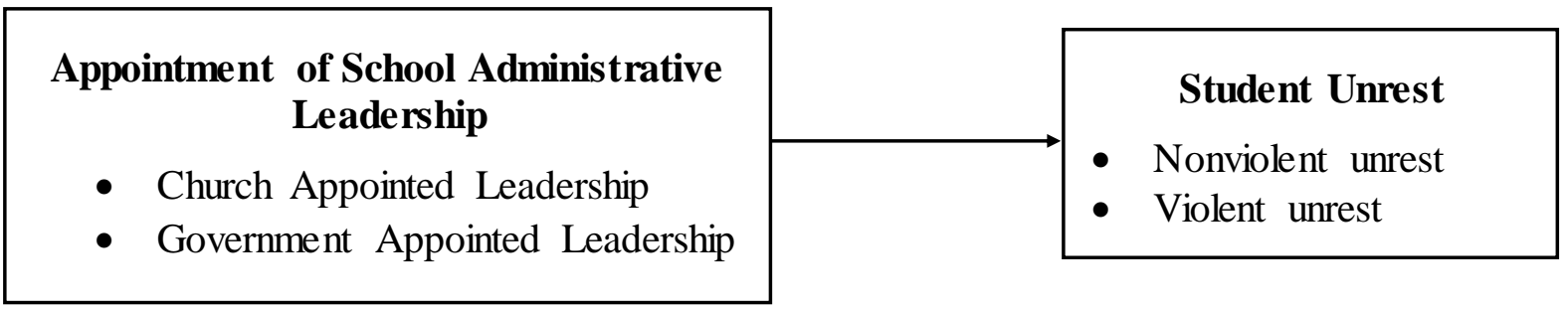

\section{Figure 1: Conceptual Framework}

\section{Source: Researcher (2021)}

\subsection{Research Methodology}

A descriptive analysis was used to give detailed information about the phenomenon. This method allowed further understanding by description of the experiences of the students. The study targeted 60 Catholic Church sponsored secondary schools in Siaya County. In each of these schools, a principal, a representative of the sponsor, and a Head student total to 180 respondents as the target population. The principals were included in the school owing to experience and knowledge on appointment of administrative leadership of schools. Student leaders' perspectives in this study were important to give their opinions on spiritual guidance, sponsorship of development projects and student unrest. Yamane (1967) sample formula was adopted to establish the sample size of 126 respondents.

$$
\mathrm{n}=\frac{\mathrm{N}}{1+\mathrm{N}\left(\mathrm{e}^{2}\right)}
$$

Where;

$\mathrm{n}=$ sample size

$\mathrm{N}=$ study population

$\mathrm{e}=$ tolerance at the preferred level of confidence

$\alpha=0.05$ at $95 \%$ confidence level.

$$
\begin{aligned}
\mathrm{n} & =180 / 1+180(0.05)^{2} \\
& =180 / 1.45 \\
& =124
\end{aligned}
$$

The Primary data was collected using questionnaires and interviews. Secondary data was documented from the selected schools. The questionnaire was administered to principals, sponsor representative and head students. The questionnaires were administered to the 124 Principals, head students and representatives of sponsors. Interviews were used to collect indepth information to provide more information from the education secretary and District Quality Assurance and Standards Officer (DQUASO). Quantitative data was analyzed by 


\section{Stratford Peer Reviewed Journals and Book Publishing \\ Journal of Education \\ Volume 4|| Issue 5 ||Page 94-107||October||2021| \\ Email: info@stratfordjournals.org ISSN: 2616-8383}

descriptive statistics. The quantitative data that was collected from the field using the structured closed ended items for the Principals, Head students, sponsors' representatives and Education Secretary were tabulated. Data analysis was then done to relate the identified factors to management of students' unrest. The qualitative data was coded by use of The Statistical Package for the Social Sciences (SPSS) Version 26 software. The study used descriptive statistical approaches to analyze the data. These included the use of frequency and percentages for the background information data and mean and standard deviation for the Likert scale data. The aspects that were included in the Pearson model were the relationship between the influence of the church sponsorship and administrative leadership, spiritual guidance and sponsorship of development projects in the management of students' unrest in Siaya County.

The researcher observed confidentiality and anonymity. Respondents were given enough information regarding the study that their participation is voluntary. All works cited were referenced and originality index report provided as part of the appendices. The researcher sought permission from relevant authorities by applying for institutional ethical approvals from The Strathmore University Institutional Ethics Review Committee (SU-IERC) and also applied for a research permit from The National Commission for Science, Technology and Innovation (NACOSTI). Upon acquiring this documentation, the researcher then sought permission from Siaya County Director of Education to collect information from the sampled list of secondary schools.

\subsection{Findings}

The researcher administered 124 questionnaires during the quantitative data collection process out of which 81 questionnaires were returned and used in the analysis. Forty three questionnaires were not returned in time and some of these were incomplete and thus did not meet the threshold of analysis. This means that the study was able to achieve a response rate of $65.3 \%$. In term of demographic information, the study found that the male respondents were $63.0 \%$ of the sample and $37.0 \%$ were female respondents. The study also found that the majority of the respondents were sponsor representatives as represented by $42.0 \%$ of the sample, head students accounted for $34.6 \%$ of the respondents and $23.5 \%$ represented the principals reached in the study.

\subsection{Church Appointment of School Administrative Leadership and Management of the Students' Unrest}

The respondents were asked to indicate level of agreement with the statements based on a five-point Likert scale. The findings indicate respondents' agreement that lack of administrative authority for decision making leads to student unrest as shown by a mean score of 4.94 and standard deviation of 1.176. This finding suggests that a vacuum of authority in secondary schools would result in a rise in student unrest. The key informant interviews indicated that lack of authority in decision making was based on the appointment of leadership without consultation with the sponsor. According to Key Informant 2:

If the Ministry of Education could collaborate and work collectively with the sponsor, maybe things would be different. Most of the student unrest has occurred in our schools because of change or transfer of principals. When the sponsor nominates a name and forwards to the Ministry and instead of endorsing, a different person is sent of a different faith, this does not go well with the school community. Sometimes there are conflicts of interest either from the sponsors' 
Stratford Peer Reviewed Journals and Book

Publishing

Journal of Education

Volume 4||Issue 5 ||Page 94-107||October||2021|

Email: info@stratfordjournals.org ISSN: 2616-8383

side or government side and these results into misunderstanding, some of the principals posted therefore will be rejected and students react to this in demonstrations or strikes. If the appointed principal has a vast experience, well qualified, is a devout catholic and suitable for the job, she/he will be accepted and school operations will run smoothly without unrest.

The descriptive findings indicated a mean score of 3.07 indicating moderate agreement that generation of suspicion and feelings of abdication of responsibility among students and other teachers has resulted in student unrest.

Table 1: Church Appointed School Administrators and Management of Student Unrest

\begin{tabular}{|c|c|c|}
\hline Statement & Mean & $\begin{array}{l}\text { Std. } \\
\text { Deviation }\end{array}$ \\
\hline $\begin{array}{l}\text { The long absence of the 'person of authority' that resides in the } \\
\text { institution in second term contributes to student unrest }\end{array}$ & 2.23 & 1.425 \\
\hline $\begin{array}{l}\text { The lack of administrative authority for decision making leads to } \\
\text { student unrest }\end{array}$ & 4.94 & 1.176 \\
\hline $\begin{array}{l}\text { The generation of suspicion and feelings of abdication of } \\
\text { responsibility among students and other teachers has resulted in } \\
\text { student unrest }\end{array}$ & 3.07 & 1.447 \\
\hline $\begin{array}{l}\text { There has been students' dissatisfaction over acting Principal's } \\
\text { off-handed administration which results in student unrest }\end{array}$ & 2.20 & 1.364 \\
\hline $\begin{array}{l}\text { Student's unrest is mostly as a revenge for disciplinary action } \\
\text { meted out to them by the school administration. }\end{array}$ & 2.73 & 1.466 \\
\hline $\begin{array}{l}\text { Rivalry between private school owners has resulted in cases of } \\
\text { student unrest }\end{array}$ & 2.49 & 1.450 \\
\hline $\begin{array}{l}\text { The expectations of the sponsor on teachers and students had a } \\
\text { significant influence on student unrest } \\
\text { The appointment of religious people to management and }\end{array}$ & 2.49 & 1.550 \\
\hline leadership of schools has contributed to student unrest & 2.35 & 1.442 \\
\hline $\begin{array}{l}\text { Parents' complaining about church appointed leadership has } \\
\text { resulted to student unrest }\end{array}$ & 2.72 & 1.451 \\
\hline $\begin{array}{l}\text { Teachers' complaining about church appointed leadership has } \\
\text { resulted to student unrest }\end{array}$ & 2.86 & 1.539 \\
\hline Overall mean score & 2.80 & 1.431 \\
\hline
\end{tabular}

The data from the secondary data shows that there are 10 Girls Boarding Schools, 5 Boys Boarding Schools, 4 Mixed Boarding Schools and 41 Mixed Day Schools sponsored by the Catholic Church. From the same data, there were a sample of 36 schools which had a church appointed administrator and 24 schools had administrators appointed by the government education authorities. Out of these schools, 15 had experienced forms of violent student unrest with much less evidence of student unrest among the church appointed administrators experiencing five student unrest ( 2 from Girls Boarding, 2 from Boys Boarding, 1 from Mixed Boarding) and ten student unrests in government administrator appointed schools (3 from Girls Boarding, 3 from Boys Boarding, 2 from Mixed Boarding and 2 from Mixed Day). Table 4.5 shows the breakdown of unrest. The findings indicate that appointing administrators by the church has a positive effect on reduced incidences of student unrest. 
Stratford Peer Reviewed Journals and Book

Publishing

Journal of Education

Volume 4||Issue 5 ||Page 94-107||October||2021|

Email: info@stratfordjournals.org ISSN: 2616-8383

Table 2: Frequency and Nature of Student Unrest

\begin{tabular}{llll}
\hline Type of school & Form & Level & Number \\
\hline Catholic church appointed & Violent & High & 5 \\
& Nonviolent & Low & 51 \\
& Situational & Managed & 4 \\
Government appointed & Violent & High & 10 \\
& Nonviolent & Low & 44 \\
& Situational & Managed & 6 \\
\hline
\end{tabular}

The researcher also aimed to determine whether there existed any statistically significant difference in management of student unrest between church and government appointed administrative leadership in the sample. A chi-square analysis was thus conducted to determine this. The findings of this analysis are presented in Table 3 which shows $\mathrm{X}^{(1)}=$ $5.926, \mathrm{p}=.015$ which tells us that there is a statistically significant difference between church appointment and government of administrative leaders and management of student.

Table 3: Chi-Square Tests

\begin{tabular}{|c|c|c|c|c|c|c|}
\hline & Value & df & $\begin{array}{l}\text { Asymptotic } \\
\text { Significance } \\
\text { sided) }\end{array}$ & (2- & $\begin{array}{l}\text { Exact Sig. } \\
\text { (2-sided) }\end{array}$ & $\begin{array}{l}\text { Exact Sig. } \\
\text { (1-sided) }\end{array}$ \\
\hline Pearson Chi-Square & $5.926^{\mathrm{a}}$ & 1 & .015 & & & \\
\hline Continuity Correction ${ }^{b}$ & 4.537 & 1 & .033 & & & \\
\hline Likelihood Ratio & 5.867 & 1 & .015 & & & \\
\hline Fisher's Exact Test & & & & & .031 & .017 \\
\hline $\mathrm{N}$ of Valid Cases & 60 & & & & & \\
\hline
\end{tabular}

a. 0 cells $(0.0 \%)$ have expected count less than 5 . The minimum expected count is 6.00 .

b. Computed only for a $2 \times 2$ table

\subsection{Correlation Analysis}

Table 4 shows positive association; church appointed administrative leadership would result in an increase in management of student unrest as indicated by a correlation of 0.235 and this was statistically significant at the 0.05 level $(p=0.035)$.

Table 4: Correlation Matrix

\begin{tabular}{lll}
\hline & & $\begin{array}{l}\text { Church appointment of } \\
\text { adminis trative leadership }\end{array}$ \\
\hline Church appointment of & & \\
administrative leadership & Pearson Correlation & 1 \\
Management of student unrest & Pearson Correlation & $.235^{*}$ \\
& Sig. (2-tailed) & 0.035 \\
\hline
\end{tabular}

The outcome of regression coefficients are used to indicate the direction and magnitude of the influence of explanatory variables on the dependent variable. The regression analysis results 


\section{Stratford Peer Reviewed Journals and Book Publishing \\ Journal of Education \\ Volume 4|| Issue 5 ||Page 94-107||October||2021| \\ Email: info@stratfordjournals.org ISSN: 2616-8383}

revealed that an increase in church appointment would result in a 0.196 increase in management of student unrest and this was significant at the 0.05 level $(p=0.005)$.

\subsection{Discussion and Conclusion}

The findings from the first objective of the study indicate that respondents were in agreement that suspicion and feelings of abdication of responsibility among students and other teachers has resulted in student unrest. This finding agrees with Onditi (2019) that revealed that in Kenyan schools, there exists lack of clear channels of communication between the head teacher and other education stakeholders, especially the students suggesting that the lack of communication between the administrative leadership and the students would result in student unrest. This is a point which was supported by Chepkawai's (2014) study which reported that through such communication, rumors, suspicions and bad plans would be done away with regarding school administration.

The second finding on this objective was respondents' agreement that a lack of administrative authority for decision making leads to student unrest. This finding agrees with those of a National Crime Research Centre (2016) report that revealed that the long durations without an authority figure residing in the institutions especially in the second term of learning resulted in a vacuum in making decisions and this created an environment of suspicion and feelings of abandoning responsibility among teachers and students. This finding does corroborates those of Chemutai, et al. (2020) who reported that students in day schools would be violent towards each other at the end of the day as there was no authority.

The correlation and regression findings indicated a positive association and effect of church appointment of school administrators and management of the students' unrest. The results from the chi-square statistics also indicated that church appointed school administrative leadership resulted in less student unrest. The findings from the study indicated that there was a difference in the number of student unrest among the church appointed school administrator schools in comparison to the government appointed school administrator schools that experienced more student unrest cases. The study results indicated that there was a statistically significant difference in management of student unrest between church appointed and government appointed school administrative leadership. The study therefore concludes that schools that have a government appointed administrator had more cases of student unrest.

\subsection{Recommendations}

The study recommends that the sponsor should actively participate in school operations for stability; facilitation of spiritual guidance and development projects. There is need for more channels of communication between students, the church, and school management on issues and matters that may result in student unrest. These communication channels should also embrace providing a space for students to be involved in decision making on school development projects for them to provide input and suggestion.

The study focused on the influence of Catholic Church sponsorship on managing student unrest in Siaya County. The study recommends for further research on church sponsorship among other denominations and also in other counties that have registered higher numbers of student unrest incidences. 
Stratford Peer Reviewed Journals and Book Publishing

Journal of Education

Volume 4||Issue 5 ||Page 94-107||October||2021|

Email: info@stratfordjournals.org ISSN: 2616-8383

\section{REFERENCES}

Amine, K (2015). 'Arab Spring' and the performance of protest in Morocco and Tunisia. Francosphères, 4(2), 157-169.

Chemutai, B., Onkware, K., \& Iteyo, C. (2020). Nature of Student Unrest in Secondary Schools in Kericho County Kenya. The International Journal of Social Sciences and Humanities Invention, 7(11), 6293-6307.

Chepkawai, R. (2014). Strategies Adopted in Dealing with Students' Unrest in Secondary Schools in Marakwet District, Kenya. Unpublished research project. Moi University. Nakuru. Kenya.

Gikungu, J. M., \& Karanja, B. W. (2014). An Epistemic Understanding of Strikes in Selected Secondary Schools Kenya. Mediterranean Journal of Social Sciences, 5(5), 191-214.

Gikungu, J. M., \& Karanja, B. W. (2014). An Epistemic Understanding of Strikes in Selected Secondary Schools Kenya. Mediterranean Journal of Social Sciences, 5(5), 191-214.

Gikungu, J. M., Karanja, B. W., \& Thinguri, R. (2014). A critical view of the historical development and concerns of curriculum in Kenya. International Journal of Education and Research, 2(5), 195-204.

Government of Kenya (2010). The Constitution of Kenya, 2010. Government Printer, Kenya.

Government of Kenya (2014). The Basic Education Act, No.14 of 2013. Government Printer: Kenya.

Hoy, W. K., Miskel, C. G., \& Tarter, C. J. (2019). Educational administration: Theory, research, and practice. (9th edition). New York, NY: McGraw-Hill.

Itumbiri, P. L. (2012). Role of church sponsors in the management of public secondary schools in Tigania West, Meru County. Unpublished research project. Mount Kenya Univesity. Thika. Kenya.

Kagwanja P. (2016). School Fires a Wakeup Call to Address Decay in Public Culture. Daily Nation, Nairobi. 
Stratford Peer Reviewed Journals and Book

Publishing

Journal of Education

Volume 4||Issue 5 ||Page 94-107||October||2021|

Email: info@stratfordjournals.org ISSN: 2616-8383

Karanja, R, \& Bowen, M. (2012). Student Indiscipline and Academic Performance in Public Schools in Kenya. Daystar University Centre for Research and Publications Working Paper Series.

Kate, U. A. (2016). Causes of Students' Unrest in Rivers State Secondary Schools: A Case Study of Federal Government Girls' College, Abuloma, Nigeria. International Journal of Education and Research, 4(11), 369-384.

Kenya Episcopal Conference (2000). Policy Document for Catholic Education in Kenya, Nairobi, Kenya, Nairobi. Paulines Publications.

Kesui, H. C., Manduku, J., \& Sang, H. (2017). Effectiveness of Guidance and Counselling Programs in Managing Indiscipline Cases in Secondary Schools in Bureti SubCounty, Kericho County, Kenya. European Journal of Education Studies, 3(10), 762744.

Kihanya, L. H. (2015). Effect of Church Sponsorship on Management of Public Secondary Schools in Kiambu Sub-County, Kenya. Unpublished research project. Kenyatta University. Nairobi. Kenya.

Mabeya, T. M., Ndiku, J M., \& Njino, J. (2010). Role of church sponsor in management of Secondary Schools: Impact on academic performance and conflict concerns in Kenya. Journal of Education Administration and Policy Studies, 2(2), 31-38.

Mosomi, B. M., \& Zachariah, W. (2017). Conflicts In The Management Of Religious Sponsored Public Secondary Schools. Experience from Kenya. European Journal of Education Studies, 3(9), 286-304.

Muindi, B. (2010). Religious Education instills discipline at Top Performing Girls' school, Nation Media Group, $28^{\text {th }}$ July, p.5, 2008, Kenya.

Muli, F. (2012). Institutional Factors Influencing Students' Unrest in Secondary Schools in Nairobi North District, Kenya. Unpublished research project. University of Nairobi. Nairobi. Kenya.

Muthamba, J. (2017). Implementation of moral education in Kenyan schools: a study of selected catholic schools from Kitui Central Deanery. Unpublished Thesis. Strathmore University. Nairobi. Kenya. 
Stratford Peer Reviewed Journals and Book

Publishing

Journal of Education

Volume 4||Issue 5 ||Page 94-107||October||2021|

Email: info@stratfordjournals.org ISSN: 2616-8383

National Crime Research Centre (2016). Rapid Assessment of Arson in Secondary Schools in Kenya. Nairobi: National Research Centre.

Odindo, C. O. (2016). Role of Religious Sponsors in management of students' discipline in Public schools in Kisumu-West Sub-County, Kenya. Unpublished Masters research project. Jaramogi Oginga Odinga University of Science and Technology. Bondo. Kenya.

Onditi, K. (2019). The Relationship between Student Leadership and Selected Correlates of School Effectiveness in Secondary Schools in Nakuru County, Kenya. Unpublished research project. Moi University. Nakuru. Kenya.

Ouma, K. M. (2015). An Evaluation of the Role of Church Sponsors in Academic Performance: A case study of Public Secondary Schools in Migori County, Kenya. Unpublished Master's Thesis. Kenyatta University. Nairobi. Kenya.

Parsons, T., \& Smelser, N. (1956). Economy and Society. New York, NY: Free Press.

Republic of Kenya (2001). Report of the Task Force on Student Discipline and Unrest (Wangai Report). Nairobi: Ministry of Education.

Republic of Kenya (2017). Report of the Special Investigation Team on school unrest 2016. Nairobi: Kenya Literature Bureau.

Romata, S.A. (Fr). (2008). Effectiveness of the Catholic Church in Reinforcing Moral Formation in Catholic Sponsored Secondary Schools in Nyeri North District. Unpublished Thesis. Catholic University of Eastern Africa. Nairobi. Kenya.

Wamunyu, J. K. (2012). Challenges Facing Public Secondary School Heads in the Management of School Projects: A Case of Mathira Constituency. Unpublished research project. University of Nairobi. Nairobi. Kenya.

Yamane, T. (1967). Statistics: An Introductory Analysis. (2nd Ed.). New York, NY: Harper and Row. 